\title{
Cognitive decline after off-pump versus on-pump coronary artery bypass graft surgery: Meta-analysis of randomized controlled trials
}

\author{
Hisato Takagi, MD, PhD, Toshiyuki Tanabashi, MD, Norikazu Kawai, MD, and Takuya Umemoto, MD, PhD, Shizuoka, \\ Japan
}

丹 Supplemental material is available online.

I $\mathrm{n}$ the randomized Octopus Study that compared off-pump with on-pump coronary artery bypass graft (CABG) surgery, van Dijk and associates ${ }^{1}$ found that avoiding the use of cardiopulmonary bypass had no effect on 5-year cognitive outcomes. On the other hand, in the same trial, off-pump CABG surgery resulted in a trend toward better cognitive outcomes 3 months after the procedure, but the effect became negligible at 12 months. ${ }^{2}$ Although the meta-analysis by Cheng and colleagues ${ }^{3}$ of 37 randomized trials showed significantly reduced neurocognitive decline at 2 to 6 months (number of trials $[N]=3$ ), significant reductions were not found at 1 month $(\mathrm{N}=3)$ or 12 months $(\mathrm{N}=$ 2). Inasmuch as only 4 studies that met their inclusion criteria contributed data to this outcome at any time point, however, the results are not inclusive enough to rule out clinically important differences. ${ }^{3}$ Therefore, to compare the effect of off-pump and on-pump CABG surgery on cognitive outcomes, we performed a meta-analysis of currently available randomized controlled trials.

\section{Materials and Methods}

All prospective randomized controlled trials of off-pump versus on-pump CABG surgery reporting the incidence of cognitive decline were identified by a 2-level search strategy. First, a public domain database (MEDLINE) was searched with a Web-based search engine (PubMed). Second, relevant studies were identified through a manual search of secondary sources including references of initially identified articles and a search of reviews and commentaries. The MEDLINE database was searched from January 1966 to February 2007. Keywords included "cognitive," "neurocognitive (neuro-cognitive)," "off pump (off-pump)," "OPCAB," and "randomized controlled trial." Studies considered for inclusion met the following criteria: the design was a prospective randomized controlled clinical trial; patients were randomly assigned to

\footnotetext{
From the Department of Cardiovascular Surgery, Shizuoka Medical Center Shizuoka, Japan.

Received for publication March 25, 2007; accepted for publication April 19, 2007.

Address for reprints: Hisato Takagi, MD, PhD, Department of Cardiovascular Surgery, Shizuoka Medical Center, 762-1 Nagasawa, Shimizu-cho, Sunto-gun, Shizuoka 411-8611, Japan (E-mail: kfgth973@ybb.ne.jp).

J Thorac Cardiovasc Surg 2007;134:512-3

$0022-5223 / \$ 32.00$

Copyright $\odot 2007$ by The American Association for Thoracic Surgery doi:10.1016/j.jtcvs.2007.04.035
}

off-pump versus on-pump CABG surgery; and main outcomes included the incidence of cognitive decline at any time point. Data regarding detailed inclusion criteria and the incidence of cognitive decline were abstracted (as available) from each individual study. For each study, data regarding the incidence of cognitive decline in both the off-pump and on-pump CABG groups were used to generate risk differences (RDs) $(<0$, favors off-pump CABG surgery; $>0$, favors on-pump CABG surgery) and $95 \%$ confidence intervals (CIs). Study-specific estimates were combined using inverse variance-weighted averages of logarithmic RDs in a randomeffects model. Between-study heterogeneity was analyzed by standard $\chi^{2}$ tests. Publication bias was assessed graphically with a funnel plot and mathematically with an adjusted rank-correlation test.

\section{Results}

Our search identified 8 prospective randomized controlled clinical trials of off-pump versus on-pump CABG surgery reporting the incidence of cognitive decline at any time point. Although only the Octopus Study ${ }^{1}$ assessed the 5-year added to within-1-year outcomes, ${ }^{2, \mathrm{E} 1}$ the remaining 7 trials reported the within-1-year outcomes. In total, our meta-analysis included data on 811 patients. Pooled analysis of the 5 trials ${ }^{\text {E1-E5 }}$ reporting the within-2week incidence of cognitive decline demonstrated a statistically nonsignificant benefit of off-pump over on-pump CABG surgery for cognitive decline (RD, $-26.8 \%$; $95 \% \mathrm{CI},-67.1 \%$ to $13.6 \%$; $P=.1935)$. There was significant trial heterogeneity of results. When data from the 6 trials $^{2, E 3, E 5-E 8}$ reporting the 1-month to 3-month incidence of cognitive decline were pooled, off-pump CABG surgery was associated with a statistically significant reduction in cognitive decline relative to on-pump CABG surgery (RD, $-8.8 \% ; 95 \% \mathrm{CI},-16.0 \%$ to $-1.6 \% ; P=.0162$ ). There was no trial heterogeneity of results. Pooled analysis of the 4 trials $^{2, \mathrm{E} 4, \mathrm{E} 5, \mathrm{E} 7}$ reporting the 6-month to 12 -month incidence of cognitive decline demonstrated a statistically nonsignificant benefit of off-pump over on-pump CABG for cognitive decline (RD, $-0.9 \%$; $95 \% \mathrm{CI},-8.7 \%$ to $6.8 \% ; P=.8127)$. There was no trial heterogeneity of results. In all the above-mentioned 3 meta-analyses, there was no evidence of significant publication bias.

\section{Discussion}

We found, on the basis of the present meta-analysis of the currently available 8 randomized controlled trials enrolling 811 patients, better cognitive outcomes 1 month to 3 months but negligible effects within 2 weeks and 6 months to 12 months after the procedure in off-pump than in on-pump CABG surgery. Our findings strengthened the inadequately proven results of the previous meta-analysis by Cheng and coworkers. ${ }^{3}$ Furthermore, according to the Octopus Study, ${ }^{1}$ better cognitive outcomes in off- 
pump CABG surgery appeared to remain absent at 5 years. These findings suggest that factors other than cardiopulmonary bypass may be responsible for cognitive decline, such as anesthesia and the generalized inflammatory response that is associated with major surgical procedures. ${ }^{1,4}$

\section{References}

1. van Dijk D, Spoor M, Hijman R, Nathoe HM, Borst C, Jansen EW, et al. Cognitive and cardiac outcomes 5 years after off-pump vs on-pump coronary artery bypass graft surgery. JAMA. 2007;297:701-8.
2. van Dijk D, Jansen EW, Hijman R, Nierich AP, Diephuis JC, Moons $\mathrm{KG}$, et al. Cognitive outcome after off-pump and on-pump coronary artery bypass graft surgery: a randomized trial. JAMA. 2002;287: 1405-12.

3. Cheng DC, Bainbridge D, Martin JE, Novick RJ; Evidence-Based Perioperative Clinical Outcomes Research Group. Does off-pump coronary artery bypass reduce mortality, morbidity, and resource utilization when compared with conventional coronary artery bypass? A metaanalysis of randomized trials. Anesthesiology. 2005;102:188-203.

4. Moller JT, Cluitmans P, Rasmussen LS, Houx P, Rasmussen H, Canet $\mathrm{J}$, et al. Long-term postoperative cognitive dysfunction in the elderly ISPOCD1 study. ISPOCD investigators. International Study of PostOperative Cognitive Dysfunction. Lancet. 1998;351:857-61. 


\section{E-References}

E1. van Dijk D, Moons KG, Keizer AM, Jansen EW, Hijman R, Diephuis JC, et al. Association between early and three month cognitive outcome after off-pump and on-pump coronary bypass surgery. Heart. 2004;90:431-4.

E2. Diegeler A, Hirsch R, Schneider F, Schilling LO, Falk V, Rauch T, et al. Neuromonitoring and neurocognitive outcome in off-pump versus conventional coronary bypass operation. Ann Thorac Surg. 2000;69: 1162-6.

E3. Zamvar V, Williams D, Hall J, Payne N, Cann C, Young K, et al. Assessment of neurocognitive impairment after off-pump and onpump techniques for coronary artery bypass graft surgery: prospective randomised controlled trial. BMJ. 2002;325:1268.

E4. Lee JD, Lee SJ, Tsushima WT, Yamauchi H, Lau WT, Popper J, et al. Benefits of off-pump bypass on neurologic and clinical morbidity: a prospective randomized trial. Ann Thorac Surg. 2003;76:18-26.
E5. Vedin J, Nyman H, Ericsson A, Hylander S, Vaage J. Cognitive function after on or off pump coronary artery bypass grafting. Eur $J$ Cardiothorac Surg. 2006;30:305-10.

E6. Lloyd CT, Ascione R, Underwood MJ, Gardner F, Black A, Angelini GD. Serum S-100 protein release and neuropsychologic outcome during coronary revascularization on the beating heart: a prospective randomized study. J Thorac Cardiovasc Surg. 2000; $119: 148-54$

E7. Lund C, Sundet K, Tennoe B, Hol PK, Rein KA, Fosse E, et al. Cerebral ischemic injury and cognitive impairment after off-pump and on-pump coronary artery bypass grafting surgery. Ann Thorac Surg. 2005;80:2126-31.

E8. Jensen BO, Hughes P, Rasmussen LS, Pedersen PU, Steinbruchel DA. Cognitive outcomes in elderly high-risk patients after off-pump versus conventional coronary artery bypass grafting: a randomized trial. Circulation. 2006;113:2790-5. 